\title{
地理学是一门脆弱的学科吗? 哈佛大学撤销地理系事件及其反思
}

\author{
叶 超 ${ }^{1}$, 尹梁明 ${ }^{1}$, 殷清眉 ${ }^{2}$,徐建华 ${ }^{1}$
}

(1. 华东师范大学地理科学学院, 上海 $200241 ; 2$. 华东师范大学城市与区域科学学院, 上海 200241)

\begin{abstract}
摘 要: 在历史上,中外地理系或地理专业被撤销或改名的事件不断重演,催生出地理学是否为一门脆弱的学科的 关键问题。文章选取在地理学思想史上有重大影响的哈佛大学撤销地理系事件作为典型案例,在分析其背景的基 础上, 根据多种文献资料, 深人透视该事件的真相及其后续影响。哈佛大学撤销地理系的原因非常复杂, 主要是科 学主义盛行的氛围、大学管理者的傲慢、自然与人文的内斗、政治因素、歧视同性恋、大学财政拨款受限、特定的时 代背景等。地理学的脆弱性实际上是学科身份认同和如何定位的问题, 它主要取决于如何处理地理学与其他学 科、社会、政府与管理部门的关系, 也就是地理学的科学性、社会性和政治性。作为一门早已独立且历史悠久的交 叉学科,地理学与其他学科、社会和政治的密切关联既是其脆弱之处,也是其优势所在。
\end{abstract}

关 键 词: 地理学; 思想史; 脆弱性; 哈佛大学撤销地理系事件

地理学是一门历史悠久、源远流长的学科。作 为一门与其他学科有着紧密关联的交叉学科, 地理 学理论的发展离不开整体科学的演进, 并受社会思 潮和实践影响(Kitchin et al, 2013)。这在使得地理 学相对容易地切人其他学科并产生新理论的同时, 也面临认同和身份危机。在中外历史上,地理机 构、地理系与地理专业被撤销或更名的事件层出不 穷。因而产生一个关键问题: 地理学是一门脆弱的 学科吗? 要透彻理解和恰当回应这一问题, 必须回 到历史, 回到那些反映该问题的具体事件中, 通过 多角度的检视, 才能有所发现。其中, 哈佛大学撤 销地理系事件无疑是影响最大的一个事件, 也是一 个透视该问题的典型案例。

1948年, 哈佛大学撤销了地质和地理部的地理 系(主要是人文地理), 解雇了几个教师, 自然地理并 人地质系, 这被称为哈佛大学撤销地理系事件(后 文简称 “哈佛事件”)。该事件具有多重效应。它是
“计量革命”的前奏或导火线一一计量革命始于 20 世纪 50 年代初期, 但直到 50 年代末才开始兴起 (Burton, 1963)。同时, 因为当时的哈佛大学是美国 地理研究的重镇, 所以该事件引发多米诺骨牌效 应, 芝加哥大学、耶鲁大学等名校也相继撤销地理 系。其后, 美国、英国、加拿大、苏联等地理学强国 甚至中国的地理学都受到冲击, 地理系或被直接取 消, 或改换门庭 (Aschmann, 1962; 孙俊, 潘玉君, 2011)。地理教育缺失的一个后果是, 普通公民尤其 是中学生, 对于世界甚至他们自己所生活的国家都 知之甚少(Downs et al, 1988; 马丁, 2008)。所以, 哈 佛事件反映出地理学身份认同的危机, 从某种程度 上也折射地理学发展的现实性问题(孙俊, 潘玉君, 和瑞芳等, 2011)。

哈佛事件的真相到底是什么? 国内外已有较 多学者对此关注并进行探究。其中, 著名地理学家 尼尔・史密斯(Neil Smith)的研究最全面、深刻和具

收稿日期: 2018-05-14; 修订日期:2018-12-18。

基金项目: 国家自然科学基金项目(41571138,41871143)。

[Foundation: National Natural Science Foundation of China, No. 41571138 and 41871143. ]

第一作者简介: 叶超(1978-), 男, 甘肃武威人, 教授, 博士生导师, 研究方向为城镇化与空间生产、地理学思想与方法、文化地 理。E-mail: yeover@163.com

引用格式: 叶超, 尹梁明, 殷清眉, 等. 2019. 地理学是一门脆弱的学科吗? 哈佛大学撤销地理系事件及其反思 [J]. 地理科学进展, 38(3): 312319. [Ye C, Yin L M, Yin Q M, et al. 2019. Is geography a vulnerable discipline? Reflections on the elimination of geography at Harvard University. Progress in Geography, 38(3): 312-319. ] DOI: 10.18306/dlkxjz.2019.03.002 
代表性(如非特别说明, 本文陈述这一事件和归纳 其原因的主要资料来源即是据此), 他认为个人、学 科、学术制度等都有责任, 但以区域地理为代表的 传统地理学的“描述、迟钝、保守”, 也就是 “3D”(Descriptive, Dull, Defensive)缺陷实际上是导致哈佛事 件的主要原因(Smith, 1987, 1988)。随后, 许多地理 学者对史密斯的论文进行了相应的回应和争辩。 地理学思想史学者杰弗里·马丁(Geoffrey Martin)对 德文特-惠特尔西(Derwent Whittlesey)和以赛亚·鲍 曼(Isaiah Bowman)在哈佛事件中的作用进行了适 度的修正(Martin, 1988); 安德鲁 - 薄瑞光 (Andrew Burghardt)(哈佛事件时的本科生)把哈佛事件归因 于地质学对资金和职位的过分追求, 以及惠特尔西 的“生活作风” (Burghardt, 1988); 索尔・科恩 (Saul Cohen)则认为哈佛事件与地理学过度依赖权威、教 学以研究生为导向、地理学结构性的弱点和易分裂 特点, 及内部建立互助网络的能力有关(Cohen, 1988)。国内学者对此事件的关注也很高, 除 Sweeper(2000)较早阐述了该事件的一些简要过程 之外, 也有人提及了哈佛事件的原因 (孙俊, 潘玉 君, 2011; 张晓祥, 2012; 袁涛, 2017)。但总体而言,
国内学界对哈佛事件及其影响的认识还不深刻和 全面。

尽管今年距离哈佛事件发生已经超过 $70 \mathrm{a}$,但 它反映的相关问题仍有重大的现实意义和参考价 值,迫切需要重新审视和评价。正所谓“前事不忘, 后事之师”。中国目前约有近百所高校设有人文地 理学学科点,此外还有相当一批高校的人文与社会 科学专业以人文地理学为基础课程 (刘云刚, 2012)。近年来,有些大学在撤销地理系,但有些大 学又成立了地理系或恢复了“地理”的名义, 这说明 地理学的脆弱性和韧性同时存在, 也进一步说明了 回顾、总结和反思这一历史事件,并从中吸取教训 和引为鉴镜的重要性。

\section{1 哈佛大学撤销地理系事件始末}

哈佛大学的地理学以地质学起家, 最早可以追 溯到纳撒尼尔・谢勒(Nathaniel Shaler)。1878年, 著 名地理学家威廉・莫里斯・戴维斯(William Morris Davis)任自然地理学教授并在 1904 年创建地理系 (表 1)。后来的关键人物鲍曼曾是戴维斯的学生。

表 1 哈佛大学地理系前后大事记

Tab.1 Major events of geography at Harvard University

\begin{tabular}{|c|c|}
\hline 时间 & 重要事件 \\
\hline 1878 年 & 戴维斯获任哈佛大学地质系的自然地理学教授 \\
\hline 1904年 & 戴维斯创建哈佛大学地理系 \\
\hline 1905 年 & 鲍曼从哈佛大学毕业(跟随戴维斯学习), 成为耶鲁大学的讲师和研究生 \\
\hline 1915 年 & 鲍曼成为美国地理学会(AGS)第一任主席 \\
\hline 1928 年 & 法国地理学家拉乌尔·布兰查德(Raoul Blanchard)任兼职教师(持续 8 年) \\
\hline 1928年 & 惠特尔西任地质与地理系人文地理学助理教授 \\
\hline 1930 年 & 肯普任哈佛地理讲师 \\
\hline 1931年 & 哈佛地理勘探研究所成立, 赖斯任教授 \\
\hline 1933 年 & 科南特获哈佛任命 \\
\hline 1935 年 & 鲍曼成为约翰·霍普金斯大学第五任校长 \\
\hline 1947年 5 月 & 阿克曼晋升为地理学副教授(赞成 7票, 反对 4票) \\
\hline 1947年6月 & 地质系教授比林斯向巴克建议将地理学和地质学分开, 并反对阿克曼晋升 \\
\hline 1948 年初 & 地理特设委员会成员建议科南特和巴克提拔阿克曼 \\
\hline 1948年2月 & 校方决定撤销地理系 \\
\hline 1948年10月 & 第一次调查委员会会议,鲍曼对撤销地理系问题保持沉默 \\
\hline 1948年10月 & 在布鲁克海文实验室会议上, 鲍曼试图向科南特解释地理学是科学的一部分 \\
\hline 1949年 5 月 & 鲍曼拒绝参加新英格兰地理会议 (乌尔曼的邀请), 对复兴哈佛地理学态度冷漠 \\
\hline 1965 年 & 费舍尔与麻省理工学院联合成立了计算机图形与空间分析实验室(LCGSA) \\
\hline 1991年 & 计算机图形与空间分析实验室解体 \\
\hline 2005 年 & 哈佛大学重建了一个“21世纪地理分析中心(CGA)” \\
\hline
\end{tabular}


在此阶段,地理学被划归地质学。

20 世纪前半期, 美国人文地理开始兴起, 地理 学也逐渐从地质学中分离。1928年, 人文地理学家 惠特尔西获任助理教授, 他一直想建设一个独立的 地理系。尽管他为地质科学部下的地理系争得一 些自主权, 特别是在课程内容安排上, 但一些决定 (尤其是关于人员任用和晋升)仍受到地质学家的限 制, 最典型的例子便是人文地理学家爱德华. 阿克 曼(Edward Ackerman)的晋升问题。

1947 年 5 月, 阿克曼晋升为地理学副教授。然 而, 地质科学学部主任马兰德・比林斯(Marland Billings) 对地质学因此损失一半职位感到不满(阿克曼 的职位被认为是半地质学半地理学), 他认为阿克 曼抢走了地质学的资源(Cresswell, 2013)。比林斯 在一些地质学教授的支持下, 向教务长保罗・巴克 (Paul Buck)建议“地理学与地质学差异很大, 两者应 该分开” (图 1)。地质学家柯特利 -马瑟 (Kirtley Mather) 与比林斯持相反的观点, 他强烈支持地理 系, 认为地质系损失一半职位的同时也会获得一半 职位。但这种观点完全被比林斯忽略。6月6日， 比林斯将反对阿克曼晋升的 3 封信正式提交给教务 长巴克。在信中, 他认为 “任何新的任命在地质学 比在人文地理学中更有价值”。比林斯选择了阿克 曼晋升问题作为攻击地理学的借口, 成为第一个对 地理学发起攻击的人物。惠特尔西不但自己写信
给巴克捍卫阿克曼的晋升,而且还邀请一些杰出学 者写信给巴克, 这些学者包括约翰・赖特 (John Wright)、理查德・哈特向(Richard Hartshorne)、胡伯 特・申克(Hubert Schenck)。

1947 年, 巴克召开了一个地理特设委员会(The Ad Hoc Committee on Geography)讨论阿克曼的晋 升问题, 委员会成员包括赖特、鲍曼, 以及哈佛大学 的校长詹姆斯・科南特(James Conant)和巴克本人 等。1948年,巴克在科南特的支持下代表校方宣布 撤销地理系, 并解聘了负责基础课程教学的理查 德・洛根(Richard Logan)、爱德华・乌尔曼(Edward Ullman)和阿克曼(图 1)。校报《哈佛深红报》(Harvard Crimson)报道认为这是一个“时代错误(Anachronous)”, 是 “少数地质学教授破坏地理学” (Harvard Crimson, 1948a, 1948b, 1948c)。阿克曼曾试图 上诉, 但没有成功。

鲍曼在哈佛事件中起着较大作用。他是约翰・ 霍普金斯大学的校长、美国地理学会主席, 和科南 特还是好友, 社会地位和影响非常突出。事实上, 作为一名自然地理学家, 鲍曼还是支持地理学作为 一门大学学科, 但同时由于其他原因, 他却对哈佛 大学地理系的发展不满, 以至于加速了哈佛大学地 理系的消亡。1949年 5 月, 以人文地理学家乌尔曼 为代表的学者曾写信力邀鲍曼参加新英格兰地理 会议,并试图呼吁“在哈佛恢复地理学”。但鲍曼以

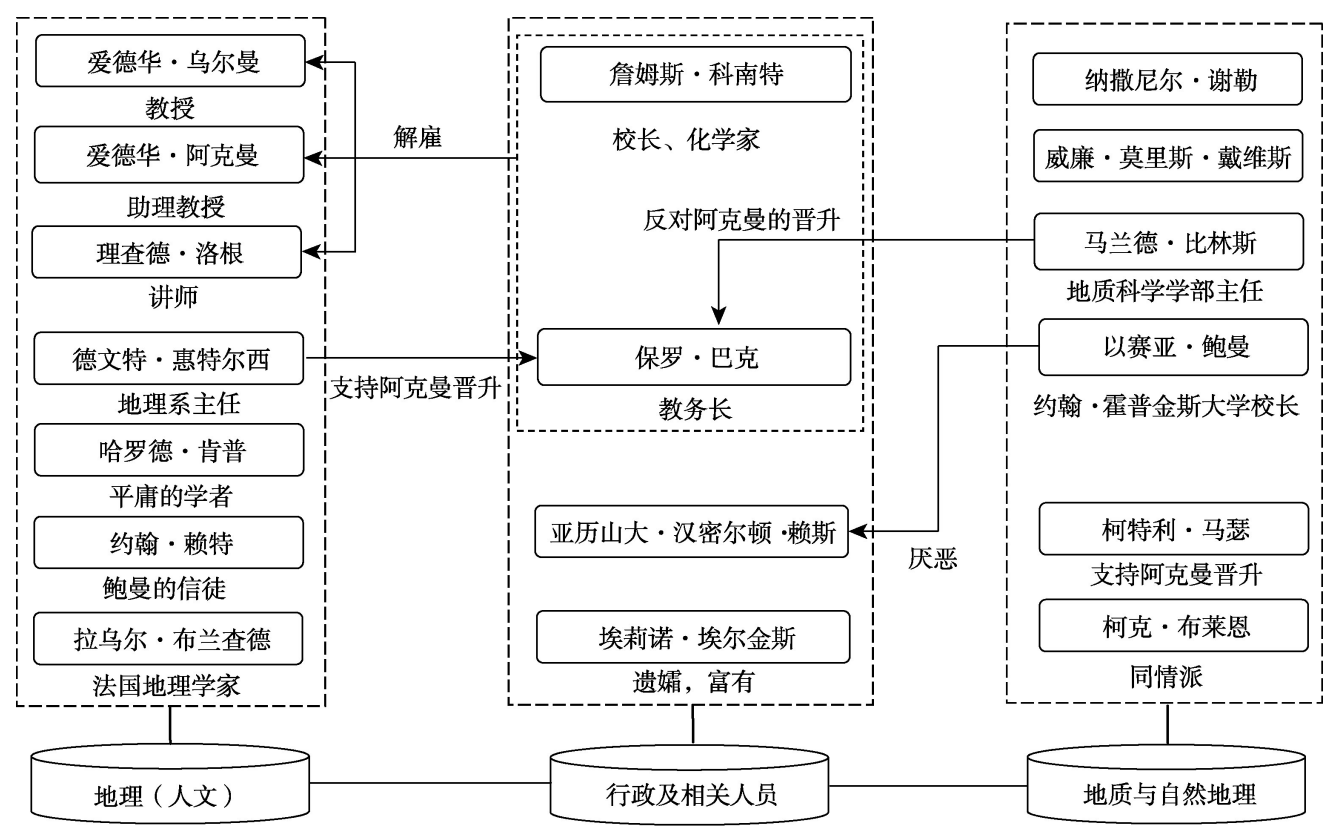

图 1 哈佛大学撤销地理系事件简图(根据 Smith, 1987 整理)

Fig.1 Simplified diagram of the elimination of geography at Harvard University (modified from Smith, 1987) 
日程繁忙为由拒绝了乌尔曼, 哈佛恢复地理系的最 后一丝希望由此破灭。

\section{2 哈佛事件发生的主要原因}

哈佛事件的发生有许多原因, 因为涉及人物众 多, 颇为复杂, 有一些至今还不清楚。但归结起来, 主要与当时科学主义盛行的学术氛围、大学管理者 的傲慢、自然与人文的内斗、抵制共产主义的政治 因素、歧视同性恋、大学财政拨款受限、当时的时代 与历史背景有关。

\section{1 科学主义与大学管理者的傲慢}

美国地理学发展早期受德国学派的影响, 既是 当时的学术潮流, 也是出于务实的考虑。早期美国 经济发展和国家的扩张促进了对自然资源和地理 环境的研究, 对地貌学和自然地理学很重视。从 20 世纪开始, 环境决定论以及社会政治问题涌现使人 文地理开始崛起。

哈佛大学校长科南特是一名化学家, 曾帮军队 制造化学武器。在第二次世界大战期间, 他获得了 较高的政治地位。教务长巴克负责哈佛大学的日 常行政管理, 是掌握地理系命运的重要人物, 但他 们对地理学并不支持。在 1947 年 6 月, 比林斯首次 反对阿克曼晋升的后 8 个月中, 巴克已经确信应该 撤销地理系(Smith, 1987)。而地质学与人文地理学 的分化趋势, 也与科南特对科学的见解不合拍 (Goldsberry, 2013)。科南特虽在 1945 年国家科学 基金会成立时认为地理学是科学,但这种观点主要 是受鲍曼的影响, 而不是基于对地理学的深刻理 解, 因而这是一种带保留意见的支持。在他看来, 人文地理学不像化学那样具有科学性, 这种偏见导 致他在地理学和地质学产生分歧时支持地质学一 方。这既反映了“科学主义”和大学管理者的傲慢, 也是当时地理学自身发展脆弱性的表现。时至今 日, 这种状况却仍然存在。

\section{2 自然与人文之间的内斗}

随着美国人文地理学的兴起, 地质学和地理学 之间的斗争和分化开始变得显著。哈佛大学地理 系在管理上属于地质学部使得这种矛盾愈发凸 显。地理系主任惠特尔西与自然地理的代表人物 鲍曼之间也势同水火。惠特尔西曾将表现平庸的 哈罗德・肯普(Harold Kemp)引进地理系, 使得同行 对其怀疑加剧(Cohen, 1988)。鲍曼早期曾试图让惠
特尔西将自己的“新世界(The New World )”改编成 高中教材, 但惠特尔西没有执行。种种纠葛使得两 人矛盾不断加剧。在惠特尔西担任美国地理学家 协会年刊主编时,鲍曼对他的办刊政策也进行批 评。哈佛大学撤销地理系后, 鲍曼写信给赖特称 “惠特尔西没有为他的学科赢得尊重”。因此, 两个 重要人物所代表的人文地理与自然地理的不合,使 得哈佛地理系雪上加霜。

\section{3 政治和社会因素}

哈佛事件发生的 1947 年, 恰是杜鲁门主义出台 之时, 标志着冷战开始,资本主义国家开始对社会 主义和共产党人进行清洗(Smith, 1988)。当时很多 保守派认为社会科学是左派激进的一个领域, 是政 治宣传的堡垒。鲍曼也持此意见。在 1945-1948 年, 鲍曼领导了许多科学家(被称为鲍曼委员会, 科 南特是成员之一)反对美国国家科学基金会将社会 科学纳人。他认为, 社会现象研究涉及人的偏见和 社会哲学, 不应与自然科学相提并论 (Martin, 1988)。这与他对人文地理学的偏见如出一辙。这 说明地理学家或科学家的政治倾向也是影响学科 发展的重要因素。

鲍曼对身为同性恋的惠特尔西一直心存厌 恶。在 1940 年底, 同性恋仍然是社会反感和避之不 及的。在右翼思想主导的阶段, 同性恋者与共产主 义者一样不被视为美国公民,而杜鲁门政府则是以 安全隐患为由,禁止或解雇已知或疑似的同性恋 者。鲍曼对同性恋的厌恶正如他对共产主义和社 会科学的态度,这使他将这种反感投射到惠特尔西 和人文地理学, 进而对撤销地理系袖手旁观。

\section{4 大学的财政约束}

大萧条(Great Depression)也是哈佛事件的一个 诱因。1945-1947年, 教学人员数量增长, 大部分 大学面临财政问题, 哈佛大学也不例外。科南特和 巴克撤销地理系的决定部分出自财务的考量。作 为私立学校, 哈佛大学发展的大部分经费来源于私 人捐款。亚历山大 ·汉密尔顿 - 赖斯 (Alexander Hamilton Rice)的妻子, 原名埃莉诺・埃尔金斯(Eleanor Elkins), 是一个富有的社会人物。1915年, 埃尔 金斯给哈佛捐赠建立了怀德纳(Widener)图书馆, 以 纪念在泰坦尼克号上去世的儿子和第一任丈夫。 大萧条初期,埃尔金斯想以向美国地理学会(American Geographical Society, AGS)提供 100 多万美元为 条件让她丈夫获得主席职位(赖斯和鲍曼都是 AGS 
主席的候选人), 但被拒绝。之后,埃尔金斯转而资 助哈佛地理研究所(Institute of Geographical Exploration), 条件是哈佛大学要授予她的丈夫赖斯教授 职位, 当时的校长阿伯特-劳伦斯・洛厄尔 (Abbott Lawrence Lowell)接受了她的条件。因此, 鲍曼等 人认为赖斯用金钱换取了哈佛大学教授的职位 (Cohen, 1988)。1931 年, 该研究所成立时, 惠特尔 西、柯克・布莱恩(Kirk Bryan)等地质科学部成员都 不与赖斯联系, 并试图让管理层与研究所分离。鲍 曼认为赖斯和研究所 “在地理研究上乏善可陈”。 捐赠人与地理系的矛盾对地理系撤销事件起了推 波助澜的作用。

\section{5 学科发展的时代背景}

哈佛事件既有偶然因素, 也有必然性。别的学 科对地理学的攻击有学科霸权和学科政治的成分, 但根本上还在于区域地理范式已不能适应社会和 学科的需求。区域地理传统主导了 20 世纪前半期, 哈特向的《地理学的性质》是代表作 (Hartshorne, 1939)。二战以后, 许多国家需要重建, 以往区域描 述的方法已经不适应现实发展的需求, 致使区域学 派发展进人瓶颈期。所以,哈佛事件之后, 1953年, 舍费尔(Fred Schaefer)发表了《地理学中的例外论: 方法论的检视》一文, 掀开了与区域派斗争的序幕 (Schaefer, 1953; Hartshorne, 1954, 1955, 1958; 叶超 等, 2009, 2012)。其后,一些年轻的学者将舍费尔 文章奉若圭臬, 开始提倡数量化、交叉化、理论化为 主导的地理研究, 掀起了 “计量革命”, 使地理学暂 时渡过难关, 最后进人一个百家争鸣的变革时期 (Ackerman, 1945; Smith, 1987; Tadaki et al, 2012)。

\section{3 地理重归哈佛?}

哈佛事件对美国地理学界产生了重大影响, 但 实际上, 虽然力量大遭削弱, 哈佛地理学发展并未 完全停步。与地理学相关的景观设计学以及霍华 德・费舍尔(Howard Fisher)为代表的计算机图形学 与空间分析实验室仍然存在。1965年, 费舍尔获得 福特基金赞助, 与麻省理工学院联合成立了计算机 图形与空间分析实验室。后来, 随着费舍尔年事渐 高, 实验室逐渐走下坡路, 并于 1991 年最终解体。 1968-1969年, 杰克・道格蒙德(Jack Dangermond) 在该实验室学习经典空间分析方法和 GIS 软件开 发技术, 并于 1969 年在其家乡建立咨询公司 ESRI
(Environmental System Research Institute)。2003 年, 由哈佛大学教务长史蒂文・埃曼(Steven Hyman) 组建的空间分析委员会(Committee on Spatial Analysis)发布了“哈佛大学空间分析报告”,宣称“我们 正在进人一个将空间数据和空间分析纳人社会文 化与物质生命科学研究的时代。计量地理学、计算 空间分析、遥感和计算机图形学等领域的进步推动 了新研究工具的开发, 以满足地球和行星科学、医 学、健康、设计和历史可视化、合成和数据分析的需 要。因此,学者和学生正在学习空间分析……哈佛 大学对空间分析和地理信息系统的兴趣已经开始 快速增长”(Richardson, 2005)。

2005 年, 在哈佛地理空间图书馆和地图图书馆 的基础上,哈佛大学建立了一个“21世纪地理分析 中心” (The Center for Geographic Analysis, CGA)。 该中心有专职人员, 可以指导涉及地理空间分析的 复杂项目,为研究以及教学开发尖端技术,包括持 续监测社会和自然环境,应用 GPS、地理信息系统 和地理空间映射技术, 提供遥感图像与矢量数据 (如 ArcGIS Explorer 和 Google Earth) 结合的系统 (The Center for Geographic Analysis at Harvard University, 2017)。2005年10月 20 日, 哈佛大学历史学 家、东亚语言与文明系查尔斯・卡斯维尔(讲座)教授 包貆德(Peter Bol)被委任为 CGA第一任主任。包怩 德提出, “自然科学、人文和社会科学研究者逐渐认 识到地理分析可以为地球、气候、动植物演变及与 人类社会相关的学科提供一个共同的基础。CGA 在大学的核心任务是搭建地理信息科学与地球行 星科学、工程、医学和公共卫生、社会学、法律、政治 学和经济学、历史和人文学科之间的桥梁。哈佛研 究人员对空间分析、空间建模、空间统计和地理信 息系统的兴趣是空间分析持续快速发展的基础”; 道格拉斯・理查森(Douglas Richardson)认为, CGA 有助于纠正过去的不足之处, 满足新的需求, 且具 有扩大和发展的巨大潜力(Richardson, 2005)。由此 可见, $\mathrm{CGA}$ 还是侧重于空间分析技术及其应用而 已, 并不是地理学整体的回归,这仍然延续着一种 与当时撤销地理系如出一辙的功利化、实用主义的 学科导向。

对哈佛大学来讲, 它当时的简单粗暴使其失去 了引领地理学发展革新的机会, 而且至今哈佛大学 并没有重建地理专业。但整个地理学却没有因为 它而失去生命。地理学这条大河源远流长, 也许偶 
尔会有枯水期,但它肯定会不息地奔流。

\section{4 结论与讨论}

哈佛事件使得地理学发展陷入低谷, 其后兴起 的计量革命使地理学又焕发生机。若无计量革命, 地理学当然可以靠着传统的主题人地关系、区域、 空间、地方等继续下去, 但如果脱离了科学发展的 大轨道, 与其他学科无法对话和渗透, 脱离了社会 现实, 那地理学也就名存实亡, 就会成为一门不人 流的学科。这提示我们, 二战后地理学发展的焦点 在于方法论上,而非研究对象。

评价一门学科或一个领域学术影响的标准有 2 个: 一是对其他科学和学术有影响, 另一是对社会 的影响。哈佛事件说明当时的地理学对其他学科 的影响甚微。不管是教务长、校长, 大学科内部的 地质学家, 还是来自其他学科的不认同都反映了当 时地理学的脆弱性。这种脆弱性实际上是因为地 理学不能在学科体系中清楚地阐明其地位和作用, 导致其他学科的人对它的认识是模糊的, 进而产生 误解。这与地理学自身缺乏革新有很大关系。所 以, 哈佛地理系被撤销的学科内外原因皆有。很多 大学相继撤销地理系, 说明在科学体系内其他学科 对地理学的认同出现了大问题。再加上区域学派 方法论不顾或远离当时的社会需求, 这是导致地理 系相继被撤销的根本原因。

从哈佛事件来看, 地理学的脆弱性主要是因为 地理学是一门科学性、社会性和政治性兼具的学 科。科学性既体现在学科内部(人文和自然)的关 系, 也体现在学科外部 (与其他学科)的关系。地理 学需要对其他学科说明自己的科学性或学术性, 如 果不能有效对话和沟通就无法得到其他学科的认 同。社会性体现在地理学是否能获得社会的认同, 而社会认同的关键主要取决于地理学能不能反映 和跟进重大社会现实问题, 能不能把地理学知识或 科学道理普及到公众当中。如果不能, 说明地理学 缺乏社会认知的普遍土壤, 就会使地理学失去至关 重要的根基, 在遇到生存危机时就无法得到社会的 支持。政治性主要体现在包括地理学在内的诸多 科学领域之间存在竞争,包括职位、权力、基金会的 支持等。学科发展也是一个政治过程, 某种意义上 讲, 任何学科都受到政治化的影响(Peet, 1998)。学 科一词的英文 discipline, 其含义是纪律或规训, 强
调遵守行业的教条和“规矩”, 这种组织化、体制化、 权力化实际上就是一个政治化的过程。地理学是 “优势”还是被边缘化的学科,实际上正反映了此问 题。虽然学科发展中权力的博峦无处不在, 但还是 存在科学性(学术性)、社会性对权力的抵制与消解, 这提示我们只有保持批判性的意识和精神, 才能正 确地协调和平衡这 3 个方面之间的关系。

近 40 年中国地理学发展过程中, 地理系撤销或 改名的事件也很多, 当然, 也有重新改回地理的事 例。但我们应该在关注这些现象之外, 深刻反思其 背后的根源与背景。如果不去反思历史并从中汲 取经验教训, 历史悲剧就会重演。只有忠实和批判 性地了解和理解历史, 才能够防止历史悲剧的重 演。只有面对真实的地理学发展过程和问题,才能 真正理解地理学的伟大和深厚, 当然, 也就能坦然 地面对学科脆弱性的问题。

哈佛事件及其影响也提醒我们,尽管地理学有 自身的学科特性,但其他学科和社会对地理学的认 同也很重要。地理学不能原地踏步, 必须变化。这 是历史, 也是事实, 更是未来的要求。变化基于传 统, 打破传统, 回到传统, 革新传统, 最后成为新的 传统。如果我们仔细研究学科的历史, 就会发现现 在的“新”, 其实只不过是已有内容的延续和深化。 历史提醒我们在说“新”时应非常谨慎,保持一种严 谨, 这是第一重作用。然而, 即使如此, 我们也要在 此基础上大胆构想和勇于超越, 冲破前人或历史的 枷锁, 尽力地发明和构建理论, 以实现我们自身的 意义和学术的价值,这是学科历史研究的第二重作 用。从历史中总结智慧, 它使我们最终破除历史的 “神秘主义”而创造新的历史, 这既需要个体的警醒 和自觉, 也需要集体的努力, 这是学科历史研究的 第三重意义。正如大卫·哈维(David Harvey)所说, “我们的任务不仅在于理解我们的地理学及其如何 形成, 我们也同样需要研究和设计一门作为学科和 立地之现实的地理学未来……联合起来我们能够 造就一个更好的世界”(引自蔡运龙等, 2016)。

\section{参考文献(References)}

Sweeper. 2012. 地理系在哈佛的灭亡与计量革命 [EB/OL]. (2012-09-07)[2018-12-18]. http://blog.sina.com.cn/s/blog 53dbe24b0101be6t.html. [Sweeper. 2012. The elimination of geography at Harvard and quantitative revolution. (2012-09-07)[2018-12-18]. http://blog.sina.com.cn/s/blog 53dbe24b0101be6t.html. ] 
蔡运龙, 叶超, 马润潮, 等. 2016. 马克思主义地理学及其中 国化: “跨国、跨界、跨代” 知识行动 [J]. 地理研究, 35(7): 1205-1229. [Cai Y L, Ye C, Ma R C, et al. 2016. Knowledge as action: Marxist geography and its development in China. Geographical Research, 35(7): 1205-1229. ]

刘云刚. 2012. 21 世纪高校人文地理学教学改革与实践: 中 山大学的探索 [J]. 人文地理, 27(2): 156-160. [Liu Y G. 2012. The practice of education curriculum reform on human geography: A case study of Sun Yat- sen University. Human Geography, 27(2): 156-160. ]

马丁. 2008. 所有可能的世界: 地理学思想史 [M]. 成一农, 王 雪梅, 译. 上海: 上海人民出版社. [Martin G J. 2008. All possible worlds: A history of geographical ideas. Translated by Cheng Y N, Wang X M. Shanghai, China: Shanghai People's Publishing House. ]

孙俊, 潘玉君. 2011. 也谈科学的兴衰: 借饶毅教授哈佛生物 学之思看地理学 [J]. 科学文化评论, 8(6): 98-104. [Sun J, Pan Y J. 2011. Talking about the rise and fall of science: Thinking geography with professor Rao Yi's thoughts on Harvard biology. Science \& Culture Review, 8(6): 98-104. ] 孙俊, 潘玉君, 和瑞芳, 等. 2011. 科学普及中行为缺失的案 例剖析: 以地理学为例 [J]. 科普研究, 6(2): 46-54. [Sun J, Pan Y J, He R F, et al. 2011. An analysis of the lack of behavior in scientific popularization: A case study of geography. Science Popularization, 6(2): 46-54. ]

叶超, 蔡运龙. 2009. 地理学方法论变革的案例剖析: 重新审 视《地理学中的例外论》之争 [J]. 地理学报, 64(9): 11341142. [Ye C, Cai Y L. 2009. Re-evaluating Schaefer and his criticizing on exceptionalism in geography: A case study on the innovation of methodology. Acta Geographica Sinica, 64(9): 1134-1142. ]

叶超, 蔡运龙. 2012. 区域地理与系统地理二元论的演变及 其透析 [J]. 地理研究, 31(5): 1-11. [Ye C, Cai Y L. 2012. Causes and effects of dualism between regional geography and systematic geography. Geographical Research, 31(5): 1-11. ]

袁涛. 2017. 哈佛大学地理系的解散与地理学的崛起 [J]. 科 技导报, 35(14): 97. [Yuan T. 2017. The dissolution of Harvard university's department of geography and the rise of geography. Science \& Technology Review, 35(14): 97. ] 张晓祥. 2012. 1948-2006: 哈佛大学地理系的灭亡与地理学 的重生 [EB/OL]. (2012-09-16)[2018-12-18]. http://blog. csdn.net/ xgis2010/ article/details/7983606. [Zhang X X. 2012. The elimination of geography at Harvard and the rebirth of geography, 1948-2006. (2012-09-16)[2018-12-18]. http://blog.csdn.net/ xgis2010/ article/details/7983606. ]

Ackerman E A. 1945. Geographic training, wartime research, and immediate professional objectives $[\mathrm{J}]$. Annals of the
Association of American Geographers, 35(4): 121-143.

Aschmann H. 1962. Geography in the liberal arts college [J]. Annals of the Association of American Geographers, 53 (3): 284-292.

Burghardt A F. 1988. On "academic war over the field of geography", the elimination of geography at Harvard, 19471951 [J]. Annals of the Association of American Geographers, 78(1): 144.

Burton I. 1963. The quantitative revolution and theoretical geography [J]. The Canadian Geographer, 7(4): 151-162.

Cohen S B. 1988. Reflections on the elimination of geography at Harvard, 1947-1951 [J]. Annals of the Association of American Geographers, 78(1): 148-151.

Cresswell T. 2013. Geographic thought: A critical introduction [M]. Oxford: Wiley-Blackwell.

Downs R M, Liben L S, Daggs D G. 1988. On education and geographers: The role of cognitive developmental theory in geographic education [J]. Annals of the Association of American Geographers, 78(4): 680-700.

Goldsberry K. 2013. The importance of spatial thinking now [J/OL]. Harvard Business Review, 2013-09-30. [2018- 12- 18]. http://blogs.hbr.org/2013/09/teaching- andlearning- visualiz/?goback=.gde_1889525_member_5793226 520059207684\#!.

Hartshorne R. 1939. The nature of geography: A critical survey of current thought in the light of the past [J]. Annals of the Association of American Geographers, 29(3): 173412.

Hartshorne R. 1954. Comment on "Exceptionalism in Geography" [J]. Annals of the Association of American Geographers, 44(1): 108-109.

Hartshorne R. 1955. Exceptionalism in geography reexamined [J]. Annals of the Association of American Geographers, 45 (3): 205-244.

Hartshorne R. 1958. The concept of geography as a science of space, from Kant and Humboldt to Hettner [J]. Annals of the Association of American Geographers, 48(2): 97-108.

Harvard Crimson. 1948a. College dooms major in geographical field [N]. Harvard Crimson, 1948-03-04.

Harvard Crimson. 1948b. Council report criticizes elimination of geography [N]. Harvard Crimson, 1948-04-21.

Harvard Crimson. 1948c. Geography loss puzzles Whittlesey [N]. Harvard Crimson, 1948-04-08.

Kitchin R, Tate N. 2013. Conducting research in human geography: Theory, methodology and practice [M]. London: Routledge.

Martin J. 1988. On Whittlesey, Bowman and Harvard [J]. Annals of the Association of American Geographers, 78(1): 
152-158.

Peet R. 1998. Modern geographical thought [M]. Oxford: Blackwell.

Richardson D. 2005. Bringing geography back to Harvard [J]. Annals Newsletter, 40(11): 1-2.

Schaefer F. 1953. Exceptionalism in geography: A methodological examination [J]. Annals of the Association of American Geographers, 43(3): 226-249.

Smith N. 1987. Academic war over the field of geography: The elimination of geography at Harvard, 1947-1951 [J]. Annals of the Association of American Geographers, 77
(2): 144 .

Smith N. 1988. For a history of geography: Response to comments [J]. Annals of the Association of American Geographers, 78(1): 159-163.

Tadaki M, Salmond J, Heron R L, et al. 2012. Nature, culture, and the work of physical geography $[\mathrm{J}]$. Transactions of the Institute of British Geographers, 37(4): 547-562.

The Center for Geographic Analysis (CGA) at Harvard University. 2017. CGA Harvard: Early history of the center [EB/ OL]. (2017-07- 25) [2018- 12- 18]. http://gis.harvard.edu/ about.

\title{
Is geography a vulnerable discipline? Reflections on the elimination of geography at Harvard University
}

\author{
YE Chao $^{1}$, YIN Liangming ${ }^{1}$, YIN Qingmei ${ }^{2}$, XU Jianhua ${ }^{1}$ \\ (1. School of Geographic Sciences, East China Normal University, Shanghai 200241, China; \\ 2. School of Urban \& Regional Science, East China Normal University, Shanghai 200241, China)
}

\begin{abstract}
The elimination of geography at Harvard University is a big event in the history of geography, which contributed to a key question whether geography is a vulnerable discipline. The elimination of geography at Harvard has a significant influence in the history of geographic thought. This article takes the elimination of geography at Harvard as a typical case and attempts to reveal the truth and the influences of the event based on the analysis of the stories in some references. The present essay is not just a case study of an important event in the history of American geography, but an opportunity for reflection and an invitation to learn from history and to apply these lessons to the present. The article argues that there were six reasons for the elimination of geography at Harvard, including the prevailing atmosphere of science, the arrogance of the university management, infighting between natural sciences and humanistic studies, the political factor of excluding communist influences, discrimination against homosexuals, university financial constraints, and the background of the particular period. The vulnerability of geography is actually a matter of identity, and is how to position the subject. It depends on how geography deals with its own relationship with other disciplines, society, the government, and management, which involves the scientific, social, and political nature of geography. As an independent interdisciplinary field with a long history, geography is closely related to other sciences, society, and politics. This is both a vulnerability and an advantage. The identity of other disciplines and societal issues are important to geography. Geography should adapt and change.
\end{abstract}

Keywords: geography; history of thought; vulnerability; elimination of geography at Harvard University 